\title{
Business History: Time for Debate
}

This issue of Business History Review, the first to be published by Cambridge University Press, is also the first to be available both in print and on line. The journal's complete archive, from 1926 forward, is also posted on the Web. ${ }^{1}$

The occasion has provided an opportunity for the editorial team to consider the work published by business historians over the past ten years, and to think about the future direction of the journal as well as of the field more broadly. We invite responses to this essay.

$\mathrm{T}$ here has rarely been a moment when the view that "history matters" has been so widespread. Scholars in economics, political science, and law are showing an ever-greater interest in history-in part as a consequence of the economic and financial crises of the past decade. Less evident is a recognition that business history itself matters as a discipline. The citations and impact factors of the business history journals lag dramatically behind top-tier management and economics journals. ${ }^{2}$ In many regions of the globe, interest in the field is small, including Latin America (except, especially, Argentina, Colombia, and Mexico), Africa (except South Africa), and many Asian countries (except Japan and South Korea).

We believe the field has great potential for growth. The Review seeks to serve the business history community by showcasing the best new research. We are proud of the quality of our articles, and we plan to continue publishing work that will drive the field forward. At $B H R$, we aspire to publish articles that are analytical, creative, and bold, and to feature book reviews that are candid and perceptive.

We especially hope to receive submissions of articles that are comparative in nature, whether the comparison be among firms, sectors, towns, regions, or countries. We encourage authors to embrace BHR.

${ }^{1}$ BHR is available through Cambridge Journals Online: http://journals.cambridge.org/

${ }^{2}$ The five-year impact factor for $B H R$ (2009) is 0.64, a score similar to that of other journals in the field. The same figure for the Quarterly Journal of Economics is 8.17; and for Academy of Management Journal is 9.26. Some of the discrepancy is due to the different sizes of the membership of these fields. But some of the reasons for the low business history scores stem from a lack of cross-disciplinary appeal.

Business History Review 85 (Spring 2011): 1-8. doi:10.1017/Sooo7680511000201 (C) 2011 The President and Fellows of Harvard College. ISSN 0007-6805; 2044-768X (Web). 
international comparisons in their project designs. There are several clusters of business historians around the globe-at Harvard Business School, New York University's Stern School of Business, the Ohio State University, the University of Tokyo, Copenhagen Business School, the Norwegian School of Management, Utrecht University, Bocconi University, L'ecole des hautes études en sciences sociales in Paris, the London School of Economics, the University of Reading, and the University of Glasgow, to name but a few places. These centers should spur the field to open itself to collaboration and dialog.

We also hope to receive articles that make use of creative and rigorous methodologies. Business history is a field that has accumulated a vast amount of empirical data, at least for some countries and industries. Major business history conferences routinely offer the work of hundreds of scholars, who cover an array of primary research material. In 2010, 175 researchers gave papers at the Business History Conference in Athens, Georgia; and 206 presented their work at the European Business History Association in Glasgow, Scotland.

Business historians should strive to make use of these rich empirical data in order to build broad generalizations. In the past, some of the greatest attainments in the field have come from scholars who drew conceptual conclusions from empirical observations. ${ }^{3}$

We believe that business historians should also utilize a wider range of methodological approaches, including those from other social sciences. At $B H R$, we see the field of business history not as a subdiscipline of history, but as a multidisciplinary field on its own.

Finally, we aim to publish articles that take on big questions: research questions to which people in many disciplines, as well as our own, want answers. Business historians in recent years have often been modest in seeking to define the critical areas of debate. It is still not uncommon to find authors framing their articles with the statement, "Chandler was wrong to suggest ...." Rehashing past controversies is not a sign of a vibrant discipline, but of one whose intellectual ambition has shrunk. Business historians have been noticeably absent from the current vigorous debates concerning the Industrial Revolution and the

\footnotetext{
${ }^{3}$ Alfred D. Chandler's concept of "strategy and structure," which arose from detailed observations of DuPont, General Motors, Sears, and Standard Oil, is one example; see Alfred D. Chandler Jr., Strategy and Structure: Chapters in the History of American Industrial Enterprise (Cambridge, Mass., 1962). Similarly, Mira Wilkins's conceptualization of the stages of multinational enterprise grew out of her careful research on individual firms. See Mira Wilkins, The Emergence of Multinational Enterprise: American Business Abroad from the Colonial Era to 1914 (Cambridge, Mass., 1970), and The Maturing of Multinational Enterprise: American Business Abroad from 1914 to 1970 (Cambridge, Mass., 1974).
} 
Great Divergence, leaving it to economists and economic historians to propel the research agendas, despite the evident role of entrepreneurs and firms in these events.

Important subjects are waiting for investigation and, above all, for debate and the development of new frameworks. Fierce argument and methodological innovation have moved academic subjects forward, not bland rejections of previous frameworks. The editorial team has identified six broad areas that hold promise. The list is neither exclusive nor prescriptive but, rather, illustrates our belief that the field must focus on important and contentious subjects where intellectual breakthroughs are possible.

1. Entrepreneurship. Entrepreneurship is an area in which business historians have made important contributions, but in which most of the recent conceptual work has been done by economists and management scholars. ${ }^{4}$ Their theories provide a more powerful set of tools for examining the history of entrepreneurship than any that were available to the pioneering business historians in the 1940 s and 1950s. Historians are now seizing the opportunity to engage with and test such theories. ${ }^{5}$ Huge areas of uncertainty regarding the causal links between entrepreneurship, innovation, and economic growth still call for explanation. It remains unclear, for instance, whether William Baumol's neat distinction between productive and unproductive entrepreneurship is borne out by historical experience.

In the last few years as well, a group of scholars has highlighted the importance of partnerships and limited partnerships in promoting entrepreneurship in Europe, the United States, and, more recently, in China and Latin America. Their research is a departure from the traditional business history focus on corporations. Business historians can profit from careful analyses of government and personal archives to reconstruct the early "start-up" phases of firms-and to uncover the role that other organizational forms, such as partnerships, played in allowing these small enterprises to grow. This kind of archival research

\footnotetext{
${ }^{4}$ For instance, business scholar Howard Stevenson developed the concept of "entrepreneurial management;" and economist William Baumol made the distinction between "productive" and "unproductive" entrepreneurship. See Howard H. Stevenson and Teresa M. Amabile, "Entrepreneurial Management: In Pursuit of Opportunity," in The Intellectual Venture Capitalist: John H. McArthur and the Work of the Harvard Business School, 19801995, ed. Thomas K. McCraw and Jeffrey L. Cruikshank (Boston, 1999); and William Baumol, "Entrepreneurship: Productive, Unproductive and Destructive," Journal of Political Economy 98, no. 3 (1990): 893-921.

${ }^{5}$ David S. Landes, Joel Mokyr, and William J. Baumol, eds., The Invention of Enterprise: Entrepreneurship from Ancient Mesopotamia to Modern Times (Princeton, 2010).
} 
gives the field an advantage over other disciplines and will allow us to answer big questions, such as, "What explains the success and failure of entrepreneurs?" 6

If business historians invest in reestablishing the entrepreneur, not only as a central actor in the history of business but also as a determinant of wealth and poverty, they will find a way back to becoming leading participants in the debates over the fundamental question of what makes an economy grow.

2. Innovation. Business historians have long explored the importance of technology and innovation in capitalist economies. They have made major contributions to understanding the routines and competencies that drive innovation in specific firms. ${ }^{7}$ Business historians have also debated the question of where innovation occurs in societywhether in large firms, in laboratories of independent inventors, or in regional clusters. ${ }^{8}$ Naomi Lamoreaux and others have also underscored the financial and regulatory conditions in which innovation has flourished..$^{9}$ Large datasets and econometric methods have enabled researchers to come up with powerful insights on these topics. Research on exhibitions in world fairs and on patent pools has questioned conventional thinking about the need for strong patent laws to encourage innovation. ${ }^{10}$ Other studies have shown that independent inventors con-

\footnotetext{
${ }^{6}$ See Naomi R. Lamoreaux, "Entrepreneurship, Business Organization, and Economic Concentration," Cambridge Economic History of the United States, vol. 2 (2000); Eric Hilt with Katharine E. O'Banion, "The Limited Partnership in New York, 1822-1858: Partnerships without Kinship," Journal of Economic History 69, no. 3 (2009); Aurora GómezGalvarriato, "Networks and Entrepreneurship: The Modernization of the Textile Business in Porfirian Mexico," Business History Review 82 (Autumn 2008); and Geoffrey Jones, Merchants to Multinationals (Oxford, 2000). Entrepreneurship can be investigated not only in individual firms, but also collectively. On this, see Alain Cottereau, "The Fate of Collective Manufactures in the Industrial World: The Silk Industries of Lyons and London, 18001850," in World of Possibilities: Flexibility and Mass Production in Western Industrialization, ed. Jonathan Zeitlin and Charles Sabel (Cambridge, U.K., 2007).

${ }^{7}$ See Margaret B. W. Graham, "Technology and Innovation," in The Oxford Handbook of Business History, ed. Geoffrey Jones and Jonathan Zeitlin (Oxford, 2008).

${ }^{8}$ See Zeitlin and Sabel, eds., World of Possibilities; and Tetsuji Okazaki, ed., Production Organizations in Japanese Economic Development (London, 2007). On the beginnings of a theory of innovation, see Thomas K. McCraw, Prophet of Innovation: Joseph Schumpeter and Creative Destruction (Cambridge, Mass., 2007). On Silicon Valley, see Christophe Lecuyer, Making Silicon Valley: Innovation and the Growth of High Tech, 1930-1970 (2006). See also Ross Thomson's Structures of Change in the Mechanical Age: Technological Innovation in the United States, 1790-1865 (Baltimore, 2009).

${ }^{9}$ See Naomi R. Lamoreaux and Kenneth L. Sokoloff, Financing Innovation in the United States, 1870 to Present (Cambridge, Mass., 2007). See also Richard R. John, Network Nation: Inventing American Telecommunications (Cambridge, Mass., 2010), which emphasizes the role of state and local governments in shaping technological change; and Gabriel Galvez-Behar, La république des inventeurs: Propriété et organisation de liinnovation en France, 1791-1922 (Rennes, 2008).
} 
tinued to play a major role in innovation in the early twentieth century, despite the rise of corporate research laboratories. Still, as Tom Nicholas suggests in a recent survey of the literature, while many scholars have documented the link between innovation and economic growth, a less well understood question is, "What drives innovation in the first place?" Historical work on institutional and cultural differences of countries-including, for instance, the defense of intellectual property rights in some countries and the neglect of counterfeiting and piracy in others-is opening up new debates and controversies on this subject. ${ }^{11}$

3. Globalization. For decades, business historians have dominated efforts to show that there is nothing new about the globalization of firms. Since the emergence of the first global economy in the nineteenth century and the growth of the first manufacturing multinationals, such as Saint-Gobain, Siemens, and Singer Sewing Machines, business historians have revealed that firms have not only responded to globalization but also driven and framed it. The study of particular industries over the long term, employing deep archival research on individual firms, has generated unique insights on evolving corporate structures, economic and social impact, and policy responses. ${ }^{12}$ Yet, in recent years, business historians have often been fringe players in the study of globalization, while political historians, economists, sociologists, and political scientists have taken it forward in exciting ways and have built a vast literature on the subject.

It is time to reengage more energetically with the broad range of globalization studies. Business historians must make the case that

\footnotetext{
${ }^{10}$ Petra Moser, "How Do Patent Laws Influence Innovation? Evidence from NineteenthCentury World Fairs," American Economic Review 95 (Sept. 2005): 1215-36; and "Do Patent Pools Encourage Innovation? Evidence from the Nineteenth Century Sewing Machine Industry," Journal of Economic History 70 (Mar. 2010): 898-920; and Zorina Kahn, The Democratization of Invention: Patents and Copyrights in American Economic Development, 1790-1920 (Cambridge, U.K., 2005).

${ }^{11}$ Tom Nicholas, "The Role of Independent Invention in U.S. Technological Development, 1880-1930," Journal of Economic History 70 (Mar. 2010); and Nicholas, "What Drives Innovation?" Antitrust Law Journal (forthcoming). See also Adrian Johns, Piracy: The Intellectual Property Wars from Gutenberg to Gates (Chicago, 2011); and on knowledge transfer, see Renate Mayntz, Friedhelm Neidhardt, Peter Weingart, and Ulrich Wengenroth, Wissensproduktion und Wissenstransfer: Wissen im Spannungsfeld von Wissenschaft, Politik und Öffentlichkeit (Bielefeld, 2008).

${ }^{12}$ Geoffrey Jones, Beauty Imagined: A History of the Global Beauty Industry (Oxford, 2010); William J. Hausman, Peter Hertner, and Mira Wilkins, Global Electrification: Multinational Enterprise and International Finance in the History of Light and Power, 1878-2007 (Cambridge, U.K., 2008); Teresa da Silva Lopes, Global Brands: The Evolution of Multinationals in Alcoholic Beverages (Cambridge, U.K., 2007); Christopher McKenna, The World's Newest Profession: Management Consulting in the Twentieth Century (Cambridge, U.K., 2006); Tony A. Freyer, Antitrust and Global Capitalism, 1930-2004 (Cambridge, Mass., 2006); and Walter A. Friedman, Birth of a Salesman: The Transformation of Selling in America (Cambridge, Mass., 2004).
} 
entrepreneurs and firms, not governments or markets, have driven and shaped globalization. At times, too, firms have mobilized governments in favor of their international expansion, as occurred in Germany and Japan, and have gained the cooperation of their states when looking for large contracts abroad. ${ }^{13}$ Business historians need to add their voices to the debate that is on everyone's minds: is globalization a positive or a negative force? Arguably, the existing evidence would suggest a less than rosy picture as firms emerge as weak transferors of knowledge and contribute to income divergence. However, the evidence is partial and patchy. Many topics, from the relations between affiliates and parents in multinational firms, to the tensions between local and global ambitions, to, finally, the impact of the globalization of firms on female career employment opportunities, remain hardly explored. ${ }^{14}$ Debate must be joined.

4. Businesses and the Environment. This journal is proud to have published pioneering articles on the history of business and the environment. ${ }^{15}$ Yet, it also has to be said that business historians have largely abnegated the job of framing the field, leaving this task to the specialized subset of environmental historians. It is odd that business historians have not devoted more attention to sustainability, given that, arguably, the actions of companies have been the primary causes of environmental damage and climate change over the last two centuries. The time has come for mainstream business history to incorporate the environmental impact of business in its agenda. The editors welcome and encourage submissions that focus on how firms have impacted the environment worldwide and attempt to develop frameworks for assessing the nature of this impact. It is equally important to identify the entrepreneurs and firms that have been ahead of governments and regulators in championing more sustainable practices and have pursued green strategies as solutions to environmental problems. ${ }^{16}$

\footnotetext{
${ }^{13}$ Laurence Badel, Diplomatie et grands contrats: L'Etat français et les marchés extérieurs au XXe siècle (Paris, 2011).

${ }^{14}$ Business History Review published a special issue on women in the international service industries in Autumn 2007. See Angel Kwolek-Folland and Margaret Walsh, "Women in the Service Industries: National Pespectives," pp. 421-27.

${ }^{15}$ See, in Business History Review: Christine Meisner Rosen, "Businessmen against Pollution in Late Nineteenth Century Chicago," 69 (Autumn 1995): 351-91; David Stradling and Joel A. Tarr, "Environmental Activism, Locomotive Smoke, and the Corporate Response," 73 (Winter 1999): 677-704; Keetie Sluyterman, "Royal Dutch Shell: Company Strategies for Dealing with Environmental Issues," 84 (Summer 2010): 203-26.

${ }^{16}$ See, for instance, Frank Uekoetter, The Age of Smoke: Environmental Policy in Germany and the United States, 1880-1970 (Pittsburgh, 2009); David Stradling and Pierre Desrochers, "How Did the Invisible Hand Handle Industrial Waste? By-product Development before the Modern Environmental Era," Enterprise \& Society 8 (June 2007): 348-74; and Peter Thorsheim, Inventing Pollution: Coal, Smoke, and Culture in Britain since 1800 (Athens, Oh., 2006).
} 
5. Role of Governments. In recent years the subject of the role of governments seems to have lost favor with business historians. In contrast, economists, among others, have launched vigorous debates on government and economic growth that center on issues of colonial governments and the impact of legal systems. Many of the arguments have been theoretically, rather than empirically, informed. ${ }^{17}$ The subject of "capitalism," too, which is thriving in American graduate history programs, appears to have the potential to envelop the field of business history. But most forays into "capitalism" fail to examine the role of the firm, perhaps the central institutional innovation of the last two centuries.

Business historians have a chance to shift debates on the subject of modern government through the use of historical evidence. Researchers are rethinking the benefits of governmental direct intervention and the role of the state as entrepreneur. Why, for example, was public ownership of infrastructure businesses common to so many European countries by the late 1940 s when they had recently come out of such disparate regimes? What accounted for the rise and decline of state-owned enterprises as a chief instrument of state intervention? ${ }^{18}$

6. Business and Democracy. The relation between business and democracy is contentious. Although many scholars since Douglass North have linked the growth of capitalist systems to their controls over executive power and their respect for individual property rights, the historical evidence raises doubts regarding any clear correlation between democracy and capitalism, as was all too evident in the part played by business in Nazi Germany. ${ }^{19}$ Looked at within a broader framework, it is evident that capitalism can flourish in undemocratic and brutal circumstances: whether in South Korean military dictatorships from the 1960 s to the 1980s; Pinochet's Chile during the 1970s and 1980s; or Communist China since 1978. Equally, business enterprises have featured regularly as saboteurs of democracy in developing countries, as

\footnotetext{
${ }^{17}$ For an exception, see Aldo Musacchio, Experiments in Financial Democracy: Corporate Governance and Financial Development in Brazil, 1882-1950 (Cambridge, U.K., 2009).

${ }^{18}$ See, for instance, Franco Amatori, Robert Millward, and Pier Angelo Toninelli, Reappraising State-Owned Enterprise: A Comparison of the UK and Italy (London, 2011); and Pier Angelo Toninelli, Louis Galambos, Franco Amatori, eds., The Rise and Fall of StateOwned Enterprise in the Western World (Cambridge, U.K., 2000).

${ }^{19}$ Business under the Nazi regime has been the focus of recent investigations, including the work of Adam Tooze, Wages of Destruction: The Making and Breaking of the Nazi Economy (New York, 2008), and Joachim Lund, Working for the New Order: European Business under German Domination, 1933-1945 (Copenhagen, 2006). For a broader discussion, see Christopher Kobrak and Per Hansen, eds., European Business, Dictatorship, and Political Risk, 1920-1945 (Oxford, U.K., 2004). There is a growing literature on government-business relations in Latin America, including Marcelo Bucheli, Bananas and Business: The United Fruit Company in Colombia, 1899-200o (New York, 2005).
} 


\section{Editorial / 8}

was the case in Guatemala, where United Fruit helped the CIA to overthrow the government in 1954. In the last decade, U.S. technology firms, such as Cisco, have supplied the Communist government in China with the routers that have permitted its government to successfully filter the Web in order to counter dissidents.

There are few more important debates than those regarding the historical relations between business and democracy, put forth ideally in order to better inform future policies and corporate actions. Why has business rarely been a force for democracy? Why has business had a poor record of resistance to totalitarian regimes, not only in Hitler's Germany but more broadly as well, whether in apartheid South Africa or contemporary China? What does history tell us about the democratic responsibilities of capitalism and firms?

The editors welcome submissions on such big topics. We would be especially pleased to see exploratory articles on these issues that draw on the historical experience of Asia, Latin America, and Africa, as we believe that many of the conceptual advances in business history over the next generation are likely to derive from a fuller understanding of those regions. We encourage dissension and debate and the construction of broad frameworks. The editors will support authors who wish to move out of their comfort zones to propose radical new ideas. In the spirit of encouraging discussion of broad topics, we will soon publish thematic issues on creative industries, consumer finance, and business and imperialism. We welcome proposals for further ambitious special issues that seek to move the discipline forward, employ rigorous methodologies, and engage wide audiences.

We believe it is time for a quantum leap in academic ambition in the field of business history, and this journal aspires to facilitate that ambition.

- Walter A. Friedman and Geoffrey Jones 